Journal of Animal and Veterinary Advances 9 (10): 1510-1514, 2010

ISSN: $1680-5593$

(C) Medwell Journals, 2010

\title{
Immunomodulatory Effects of Graded Copper and Zinc on SRBC Titer and Lymphoid Organs in Broiler Chicks
}

\author{
J. Arshami, S. Hosseini and M.E. Torshizi \\ Department of Animal Sciences, Faculty of Agriculture, \\ Ferdowsi University of Mashhad, Mashhad 91775-1163, Iran
}

\begin{abstract}
A total of 400 pieces of day-old male broiler chicks were distributed into 9 treatments and one control diet with 4 replicates using a CRD design ( $3 \times 3$ factorial). Chicks for 42 days received graded levels of $\mathrm{Cu}$ $\left(35,70,105 \mathrm{mg} \mathrm{kg}^{-1}\right.$ diet) and $\mathrm{Zn}\left(40,80,120 \mathrm{mg} \mathrm{kg}^{-1}\right.$ diet) in their diets (free of $\mathrm{Cu}$ and $\mathrm{Zn}$ mineral premix) to determine the antibody titer of SRBC and the weights of lymphoid organs (BW\%) including: Thymus (TW), Bursa (BW), Spleen (SW) and Liver (LW). On days 28 and 35, two birds from each pen received SRBC ( $1 \mathrm{~mL}$, $10 \%$ ) injections and were bled 7 days after each inoculation to evaluate the primary and secondary responses for Total Immunoglobulin (TIg), Immunoglobulin M (IgM) and Immunoglobulin Y (Ig Y). On day 42, two birds from each pen were slaughtered to weigh the lymphoid organs. Since analysis of data showed no significant interaction between graded $\mathrm{Cu}$ and zinc, only the main effect of means were considered. The graded $\mathrm{Cu}$ increased titers of TIg and IgY linearly but reduced IgM titer quadratically in primary response. In secondary response, the titers of TIg and IgM decreased, but IgY increased quadratically. The graded Zn increased TIg and decreased $\operatorname{IgM}$ titers quadratically but the titer of $\operatorname{Ig} Y$ increased linearly in primary response. In secondary response, the graded $\mathrm{Zn}$ increased $\mathrm{IgM}$ titer but decreased $\mathrm{TIg}$ and $\mathrm{IgY}$ titers quadratically. The graded $\mathrm{Cu}$ enhanced TW and SW linearly but BW and LW $(\mathrm{p}<0.05)$ quadratically. The graded Zn increased TW and decreased BW linearly but decreased SW and LW quadratically. Overall results indicated that adding $\mathrm{Cu}$ at 70-105 ppm and $\mathrm{Zn}$ at 80-120 ppm improved SRBC titers and weights of lymphoid organs. In conclusion, adding $\mathrm{Cu}$ and $\mathrm{Zn}$ at recommended levels can be useful as immunomodulators in broiler chicks.
\end{abstract}

Key words: SRBC titer, lymphoid organs, copper and zinc, broiler chicks, BW, Iran

\section{INTRODUCTION}

The poultry industry relies on the application of antibiotics or related medications to improve disease resistance within poultry flocks. However, this practice has accompanied with the prevalence and establishment of antibiotic-resistant species within the human population (Ratcliff, 2000).

It is well known that trace elements in animal diets play a critical role on the modulation of immune responses (Klasing, 1998; Kidd, 2004). Copper and Zn are vital minerals and essential nutrient requirements for growth and development (Schumann et al., 2002; McCall et al., 2000).

Copper plays an important role in development and maintenance of the immune system (Percival, 1998). In experimental animals fed $\mathrm{Cu}$-deficient diets, the antibodies forming cell response, decreased (Prohaska and Lukasewycz, 1981; Vyas and Chandra, 1983). Suttle and Jones (1986) found that Cu-deficient animals showed a decrease in antibody cell response along with increased susceptibility to infections. Zinc is a critical element for proper immune functions in animals and its deficiency decreased cellular immunity (Fletcher et al., 1988) of thymus (Fraker et al., 1977) and spleen (Leucke et al., 1978). A higher concentration of $\mathrm{Zn}$ is commonly added to poultry diets for its deficiency under commercial conditions due to poor availability in plants (Ellise et al., 1982).

Some studies observed that small increase in $\mathrm{Zn}$ consumption (NRC, 1994) depressed $\mathrm{Cu}$ status in experimental animals (L'Abbe and Fischer, 1984) and human (Fischer et al., 1984; Yadrick et al., 1989).

Most nutrient requirements in broilers particularly vitamins and trace minerals are used based on researches conducted 40 years ago for old sues (Waldroup, 2004). Therefore, the aim of this study was to determine the effects of graded $\mathrm{Cu}$ and $\mathrm{Zn}$ on SRBC titer and lymphoid organs in new sues of broiler chicks.

Corresponding Author: J. Arshami, Department of Animal Sciences, Faculty of Agriculture, Ferdowsi University of Mashhad, Mashhad 91775-1163, Iran 


\section{MATERIALS AND METHODS}

Birds and treatments: This study was conducted at experimental animal house, Ferdowsi University of Mashhad (FUM), Department of Animal Sciences. Four hundred pieces of day-old (Ross 308) male broiler chicks randomly assigned to 40 pens as 9 treatments and one control diet with 4 replicates using a CRD design $(3 \times 3$ factorial). The treatments including $\mathrm{Cu}(35,70$, $105 \mathrm{mg} \mathrm{kg}^{-1}$ diet $)$ and $\mathrm{Zn}\left(40,80,120 \mathrm{mg} \mathrm{kg}^{-1}\right.$ diet) were added to basal ration (control diet; NRC, 1994) with minimum amounts of these minerals ( 3.9 and $3.1 \mathrm{mg} \mathrm{kg}^{-1}$ $\mathrm{Cu}$ and 19.09 and $17.31 \mathrm{mg} \mathrm{kg}^{-1} \mathrm{Zn}$ ) during starter and grower periods, respectively (Table 1). Chicks were maintained in a thermostatically-controlled room and had access to free water and feed during 42 days.

SRBC test: humoral antibody response: The SRBC (sheep red blood cell) test was performed to quantify the specific antibody titer. On days 28 and 35 , two birds from each pen were immunized intraperitoneally using $1 \mathrm{~mL}$ of $10 \%$ SRBC suspension. Seven days after SRBC inoculation, the birds were bled by brachial venipuncture

Table 1: Ingredients and composition (\%,DM basis) of experimental diets in broilers during starter and grower periods

\begin{tabular}{|c|c|c|}
\hline Ingredients & Starter (1-21 days) & Gower ( $21-42$ days) \\
\hline Corn & 54.40 & 64.63 \\
\hline Soybean meal & 39.01 & 31.00 \\
\hline Oil & 2.33 & 1.00 \\
\hline Limestone & 1.29 & 1.25 \\
\hline Dicalcium phosphate & 1.85 & 1.20 \\
\hline Common salt & 0.46 & 0.35 \\
\hline Mineral premix ${ }^{1}$ & 0.25 & 0.25 \\
\hline Vitamin premix ${ }^{2}$ & 0.25 & 0.25 \\
\hline DL-methionine & 0.16 & 0.07 \\
\hline \multicolumn{3}{|l|}{ Nutrient composition } \\
\hline $\mathrm{ME}\left(\mathrm{Kcal} \mathrm{kg}^{-1}\right)$ & 3018.00 & 3050.00 \\
\hline Crude protein $(\%)$ & 21.65 & 19.06 \\
\hline Ether extract (\%) & 4.71 & 3.70 \\
\hline Crude fiber $(\%)$ & 2.72 & 2.63 \\
\hline $\mathrm{Ca}(\%)$ & 1.00 & 0.83 \\
\hline $\mathrm{P}(\%)$ & 0.48 & 0.35 \\
\hline $\mathrm{Na}(\%)$ & 0.20 & 0.15 \\
\hline Arginine $(\%)$ & 1.56 & 1.32 \\
\hline Lysine (\%) & 1.37 & 1.10 \\
\hline Met + cys (\%) & 0.90 & 0.72 \\
\hline Methionine & 0.50 & 0.38 \\
\hline Zinc $\left(\mathrm{mg} \mathrm{kg}^{-1}\right)$ & 19.09 & 17.31 \\
\hline Copper $\left(\mathrm{mg} \mathrm{kg}^{-1}\right)$ & 3.90 & $3.1^{0}$ \\
\hline \multicolumn{3}{|c|}{ 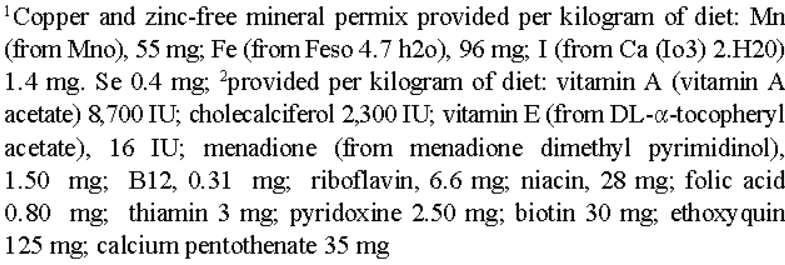 } \\
\hline
\end{tabular}

and $3 \mathrm{~mL}$ of blood was collected to evaluate the primary and secondary antibody responses. The sera were inactivated by heat at $56^{\circ} \mathrm{C}$ for $30 \mathrm{~min}$. Then, they were assayed for total anti-SRBC (TIg), 2-mercaptoethanolsensitive antibody (2ME-S, IgM) and 2-mercaptoethanolresistant antibody (2ME-R, IgG) using a method described by Qureshi and Havenstein (1994). Briefly, $50 \mu \mathrm{L}$ of serum was added to $50 \mu \mathrm{L}$ PBS of the first column in a 96-well $\mathrm{v}$-shaped bottom plate and then the solution was incubated for $30 \mathrm{~min}$ at $37^{\circ} \mathrm{C}$.

A serial of dilution was prepared as 1:2 and then $50 \mu \mathrm{L}$ of $2 \%$ SRBC suspension was added to each well. The plates were read on a microplate reader at $650 \mathrm{~nm}$ (Molecular Devices, Sunnyvale, CA 94089) to evaluate the TIg titer against SRBC after $30 \mathrm{~min}$ of incubation at $37^{\circ} \mathrm{C}$. Immediately, the well with a distinct SRBC bottom was considered as the endpoint of titer for agglutination.

To evaluate $2 \mathrm{ME}-\mathrm{S}$ (IgM) response, first $50 \mu \mathrm{L}$ of $0.01 \mathrm{moL}$. of $2 \mathrm{ME}$ in PBS was used and then followed the previous procedure. The difference between $\mathrm{TIg}$ and $\mathrm{IgG}$ responses was considered as IgM titer.

Lymphoid organs: On the last day of trial, two randomlyselected birds from each replicate were weighted and slaughtered by cervical cutting. Thymus, spleen, bursa of fabricius and liver were precisely removed and weighted by a sensitive digital scale then calculated as percentage of body weight.

Statistical analysis: Collected data from the experiment was carried out in a CRD design ( $3 \times 3$ factorial) (Steel and Torrie, 1980). The data were subjected to ANOVA

Table 2: Main effect means of anti-SRBC antibody responses (primary and secondary) of broilers fed different levels of copper and zinc

\begin{tabular}{|c|c|c|c|c|c|c|}
\hline \multirow[b]{2}{*}{ Metal } & \multicolumn{3}{|l|}{ Primary } & \multicolumn{3}{|c|}{ Secondary } \\
\hline & Total $\mathrm{Ig}^{2}$ & $\operatorname{Ig}^{2}$ & $\operatorname{IgY}^{2}$ & Total $\mathrm{Ig}^{2}$ & $\operatorname{Ig}^{2}$ & $\operatorname{IgY}^{2}$ \\
\hline \multicolumn{7}{|l|}{$\mathrm{Cu}$} \\
\hline 35 & 3.95 & 1.33 & 2.62 & 5.87 & 1.95 & 3.91 \\
\hline 70 & 4.09 & 1.36 & 2.72 & 5.88 & 2.12 & 3.75 \\
\hline 105 & 4.38 & 1.22 & 3.16 & 5.36 & 1.27 & 4.09 \\
\hline SE & 0.53 & 0.27 & 0.43 & 0.31 & 0.33 & 0.36 \\
\hline 40 & 3.40 & 1.27 & 2.13 & 5.63 & 1.79 & 3.95 \\
\hline \multicolumn{7}{|l|}{$\mathrm{Zn}$} \\
\hline 80 & $4 / 54$ & 1.63 & 2.90 & 5.87 & 1.70 & 4.16 \\
\hline 120 & 4.45 & 1.00 & 3.45 & 5.62 & 2.00 & 3.62 \\
\hline SE & 0.53 & 0.27 & 0.43 & 0.31 & 0.33 & 0.36 \\
\hline \multicolumn{7}{|c|}{$\begin{array}{l}\text { Statistical effects } \\
\text { p-value }\end{array}$} \\
\hline $\mathrm{Cu}$ & 0.68 & 0.37 & 0.44 & 0.48 & 0.31 & 0.88 \\
\hline $\mathrm{Zn}$ & 0.38 & 0.62 & 0.22 & 0.82 & 0.82 & 0.57 \\
\hline $\mathrm{Cu} \times \mathrm{Zn}$ & 0.99 & 0.83 & 0.82 & 0.16 & 0.53 & 0.23 \\
\hline $\operatorname{Zn}(\operatorname{lin})^{3}$ & 0.28 & 0.38 & 0.09 & 0.92 & 0.63 & 0.62 \\
\hline Control vs. all ${ }^{4}$ & 0.04 & 0.99 & 0.04 & 0.23 & 0.23 & 0.16 \\
\hline
\end{tabular}


Table 3: Main effect means of lymphoid organ and liver weights of 42 days old broilers fed different levels of copper and zinc (\%BW)

\begin{tabular}{|c|c|c|c|c|}
\hline Metal & Thymus & Bursa & Spleen & Liver \\
\hline \multicolumn{5}{|l|}{$\mathrm{Cu}(\mathrm{ppm})$} \\
\hline 35 & 0.322 & 0.091 & 0.105 & $1.741^{b}$ \\
\hline 70 & 0.323 & 0.088 & 0.108 & $2.557^{\mathrm{a}}$ \\
\hline 105 & 0.378 & 0.100 & 0.126 & $2.06^{\mathrm{ab}}$ \\
\hline SE & 0.045 & 0.015 & 0.007 & 0.190 \\
\hline \multicolumn{5}{|l|}{$\mathrm{Zn}$ (ppm) } \\
\hline 40 & 0.314 & 0.111 & 0.112 & 1.857 \\
\hline 80 & 0.318 & 0.089 & 0.118 & 2.379 \\
\hline 120 & 0.386 & 0.079 & 0.107 & 2.105 \\
\hline SE & 0.045 & 0.015 & 0.007 & 0.190 \\
\hline \multicolumn{5}{|c|}{$\begin{array}{l}\text { Statistical effects } \\
\text { p-value }\end{array}$} \\
\hline $\mathrm{Cu}$ & 0.508 & 0.688 & 0.097 & 0.066 \\
\hline $\mathrm{Zn}$ & 0.537 & 0.244 & 0.555 & 0.604 \\
\hline $\mathrm{Cu} \times \mathrm{Zn}$ & 0.569 & 0.230 & 0.201 & 0.350 \\
\hline $\mathrm{Cu}(\operatorname{lin})^{1}$ & 0.311 & 0.500 & 0.040 & 0.735 \\
\hline $\mathrm{Cu}$ (quad) ${ }^{1}$ & 0.572 & 0.580 & 0.390 & 0.020 \\
\hline Control vs. all ${ }^{2}$ & 0.380 & 0.850 & 0.080 & 0.740 \\
\hline
\end{tabular}

according to GLM procedure of SAS Institute (2005) software. The main effect of means was compared at significant level of $\mathrm{p}<0.05$ using a Duncan (1955)'s multiple range test. Since we had no significant interaction between graded $\mathrm{Cu}$ and $\mathrm{Zn}$, only the main effect means were considered (Table 2 and 3 ). All data were checked for normality using Shapiri-Wilk test.

\section{RESULTS AND DISCUSSION}

Humoral antibody response (SRBC): Data analysis showed no significant interaction between graded $\mathrm{Cu}$ and Zinc. The main effect means of antibody titers by graded $\mathrm{Cu}$ and $\mathrm{Zn}$ on primary and secondary responses of SRBC are shown in Table 2. The primary and secondary responses of anti-SRBC titer in broilers fed different levels of $\mathrm{Cu}$ and $\mathrm{Zn}$ showed no significant effects. Contrast comparison between control and treatment diets showed improvement of $\mathrm{TIg}$ and $\mathrm{Ig} \mathrm{Y}$ in primary response $(\mathrm{p}<0.05)$. The graded $\mathrm{Cu}$ increased titers of TIg and Ig Y linearly but $\operatorname{IgM}$ reduced quadratically in the primary response. In the secondary response, the titers of $\mathrm{TIg}$ and $\operatorname{IgM}$ were reduced but $\mathrm{Ig} \mathrm{Y}$ was induced quadratically. Up to now, not too many studies concerning different levels and sources of $\mathrm{Cu}$ on SRBC titers have been done. Earlier study showed that $\mathrm{Cu}$ has an important role on development of immune system (Mulhern and Koller, 1988). Fischer et al. (1984) reported that $\mathrm{Cu}$ absorption decreased as the dietary $\mathrm{Zn}$ increased. Accordingly, it seems that low levels of $\mathrm{Zn}$ in diet can display $\mathrm{Cu}$ roles on improvement of immune system. But the finding showed some enhancement in humoral antibody response to graded $\mathrm{Cu}$ in broiler chicks. Bartlett and Smith (2003) reported that high organic $\mathrm{Zn}$ diet increased $\mathrm{TIg}, \operatorname{IgM}$ and IgG titers in birds in comparison with adequate or low organic $\mathrm{Zn}$ diets during primary response $(\mathrm{p}<0.05)$. Whereas in the study, the graded $\mathrm{Zn}$ increased TIg and decreased $\operatorname{Ig} M$ titers quadratically but the titer of $\operatorname{IgY}$ increased linearly in the primary response.

Conversely, in the secondary response, the graded $\mathrm{Zn}$ increased $\operatorname{Ig} \mathrm{M}$ titer but decreased titers of TIg and $\operatorname{Ig} \mathrm{Y}$ quadratically. Although, the graded $\mathrm{Zn}$ increased IgY titer in primary response linearly $(p=0.09)$. It seems that the source of $\mathrm{Zn}$ affects differently on the titer of SRBC and organic sources have higher bioavailability compared to inorganic sources. Similarly, Pimentel et al. (1991) reported that excess levels of $\mathrm{Zn}$ enhanced IgG titer on day 9 after SRBC inoculation. On the other hand, Virden et al. (2004) observed that primary antibody response to SRBC didn't differ between treatments in progeny of broiler breeders fed diets with different levels and sources of zinc.

Relative lymphoid organ weights: Since there was no significant interaction between $\mathrm{Cu}$ and $\mathrm{Zn}$ at 42 days of age on organ weights in broilers, only the main effect means of lymphoid organ weights were considered in Table 3 . The $\mathrm{LW}$ was affected by dietary $\mathrm{Cu}$ with the highest for $70 \mathrm{ppm}(\mathrm{p}<0.05)$. The response of TW, BW and $\mathrm{SW}$ to $\mathrm{Cu}$ levels followed a linear trend with a significant increase for SW up to $105 \mathrm{ppm}(\mathrm{p}<0.05)$. In addition, the trend of LW responded quadratically $(\mathrm{p}<0.02)$. In contrast, Arias and Koutsos (2006) reported no significant differences between treatments containing $\mathrm{Cu}$ sulfate and control group in broilers. In the study, the increase in LW at 70-105 ppm Cu level $(\mathrm{p}<0.05)$ may be caused by cell proliferations and or $\mathrm{Cu}$ accumulation in the liver.

Previous reports showed that a diet deficient in $\mathrm{Zn}$ led to atrophy of thymus (Prasad and Oberleas, 1971) and reduction of SW in rats (Mengheri et al., 1988). In contrast, the results indicated that the graded $\mathrm{Zn}$ increased TW and LW linearly and quadratically, respectively. Furthermore, several studies reported that $\mathrm{Zn}$ deficiency caused thymus (50\% of normal) (Dowd et al., 1986) and spleen involution (61\% of normal) (Leuck et al., 1978) and depression of immune functions in mice and rats (Beach et al., 1980). On the other hand, the birds that received high, low or adequate $\mathrm{Zn}$ showed no effects on TW, SW and BW (Bartlett and Smith, 2003). Conversely, the results revealed that the TW and LW increased linearly and quadratically, respectively. These inductions perhaps are related to accumulation of $\mathrm{Zn}$ and or proliferation of the cells in the organs. 


\section{CONCLUSION}

Considering the results, the graded $\mathrm{Cu}$ at 70-105 and $\mathrm{Zn}$ at $40-80 \mathrm{ppm}$ improved SRBC titer and weights of some lymphoid organs in male broiler chicks. In conclusion, adding $\mathrm{Cu}$ and $\mathrm{Zn}$ at recommended levels can be used as immunomodulators. Apart from present study, further researches should be done to determine the exact levels of $\mathrm{Cu}$ and $\mathrm{Zn}$ with different sources of these elements in this ground.

\section{ACKNOWLEDGEMENTS}

This study was supported by a grant from the Research Center of Ferdowsi University of Mashhad (FUM), Iran. Special thank goes to Mr. Pilevar (MS.c, Physiology) for his assistant.

\section{REFERENCES}

Arias, V.J. and E.A. Koutsos, 2006. Effects of copper source and level on intestinal physiology and growth of broiler chickens. Poult. Sci., 85: 999-1007.

Bartlett, J.R. and M.O. Smith, 2003. Effects of different levels of zinc on the performance and immunocompetence of broilers under heat stress. Poult. Sci., 82: 1580-1588.

Beach, R.H., M.E. Gershwin and L.S. Hurley, 1980. Impaired immunological ontogeny in post-natal zinc deprivation. J. Nutr., 110: 805-810.

Dowd, P.S., J. Kelleher and P.J. Guillou, 1986. Tlymphocyte subsets and interleukin-2 production in zinc-deficient rats. Br. J. Nutr., 55: 59-69.

Duncan, D.B., 1955. Multiple range and multiple F-tests. Biometrics, 11: 1-42.

Ellis, R., E.R. Morris and A.D. Hill, 1982. Bioavailability to rats of iron and zinc in calcium-iron-phytate and calcium-zinc-phytate complex. Nutr. Res., 2: 319-322.

Fischer, P.W., A. Giroux and M.R. L'Abbe, 1984. Effect of zinc supplementation on copper status in adult man. Am. J. Clin. Nutr., 40: 743-746.

Fletcher, M.P., M.E. Gershwin, C.L. Keen and L.S. Hurley, 1988. Trace Element Deficiencies and Immune Responsiveness in Human and Animal Models. In: Nutrition and Immunology, Chandra, R.K. (Ed.). Alan, R. Liss Inc., New York, USA., pp: 215-239.

Fraker, P.J., S.M. Haas and R.W. Leucke, 1977. Effect of zinc deficiency on the immune response of the young adult A/J mouse. J. Nutr., 107: 1889-1895.

Kidd, M.T., 2004. Nutritional modulation of immune function in broilers. Poult. Sci., 83: 650-657.
Klasing, K.C., 1998. Nutritional modulation of resistance to infectious diseases. Poult. Sci., 77: 1119-1125.

L'Abbe, M.R. and P.W. Fischer, 1984. The effects of dietary zinc on the activity of copper-requiring metalloenzymes in the rat. J. Nutr., 114: 823-828.

Leucke, R.W., C.E. Siminol and P.J. Fraker, 1978. The effect of restricted dietary intake on the antibody mediated response of the zinc deficient $\mathrm{A} / \mathrm{J}$ mouse. $\mathrm{J}$. Nutr., 108: 881-887.

McCall, K.A., C. Huang and C.A. Fierke, 2000. Function and mechanism of Zinc metalloenzymes. J. Nutr., 130: 1437-1446.

Mengheri, E., G. Bises and S. Gaetani, 1988. Differentiated cell-mediated immune response in zinc deficiency and in protein malnutrition. Nutr. Res., 8: 801-812.

Mulhern, S.A. and L.D. Koller, 1988. Severe or marginal copper deficiency results in a graded reduction in immune status in mice. J. Nutr., 118: 10-41.

NRC. (National Research Council), 1994. Nutrient Requiremants of Poultry. 9th Rev. Edn., Natl. Acad. Press, Washington, DC., USA., pp: 176.

Percival, S., 1998. Copper and immunity. Am. J. Clin. Nutr., 57: 1064-1068.

Pimentel, J.L., M.E. Cook and J.L. Ggreger, 1991. Immune response of chicks fed various levels of zinc. Poult. Sci., 70: 947-954.

Prasad, A.S. and D. Oberleas, 1971. Changes in activities of zinc dependent enzymes in zinc dependent tissues of rats. J. Applied Physiol., 31: 842-848.

Prohaska, J.R. and O.A. Lukasewycz, 1981. Copper deficiency suppresses the immune response of mice. Science, 213: 559-561.

Qureshi, M.A. and G.B. Havenstein, 1994. A comparison of the immune performance of a 1991 commercial broiler with a 1957 randombred strain when fed typical 1957 and 1991 boiler diets. Poult. Sci., 73: 1805-1812.

Ratcliff, M.M., 2000. Dying inside the walls. J. Palliat. Med., 3: 509-511.

SAS Institute Inc., 2005. SAS/STAT User's Guide: Version 9.1. SAS Institute Inc., Cary NC.

Schumann, K., H.G. Classen, H.H. Dieter, J. Konig and G. Multhaup et al., 2002. Hohenheim consensus workshop: Copper. Eur. J. Clin. Nutr., 56: 469-483.

Steel, R.G.D. and J.H. Torrie, 1980. Principles and Procedures of Statistics: A Biometrical Approach. 2nd Edn., McGraw Hill, New York, USA., ISBN-13: 978-0070609259. 
Suttle, N.F. and D.G. Jones, 1986. Copper and disease resistance in sheep: A rare natural confirmation of interaction between a specific nutrient and infection. Proc. Nutr. Soc., 45: 317-321.

Virden, W.S., J.B. Yeatman, S.J. Barber, K.O. Willeford and T.L. Ward et al., 2004. Immune system and cardiac functions of progeny chicks from dams fed diets differing in zinc and manganese level and source. Poult. Sci., 83: 344-351.
Vyas, D. and R.K. Chandra, 1983. Thymic factor activity, lymphocyte stimulation response and antibody-producing cell in copper deficiency. Nutr. Res., 3: 343-349.

Waldroup, P.W., 2004. Dietary nutrient allowances in chickens and turkeys. Feedstuffs, 76: 42-47.

Yadrick, M.K., M.A. Kenney and E.A. Winterfeldt, 1989. Iron, copper and zinc status: Response to supplementation with zinc or zinc and iron in adult females. Am. J. Clin. Nutr., 49: 145-150. 